\title{
Comparative Study of the Salinization Process in Surface Water Reservoirs Located in Two Distinct Regions in Southwestern Bahia, Brazil
}

\author{
José S. dos Santos, * Maria Lúcia P. dos Santos and Daniela Marques Alexandrino \\ Departamento de Ciências Naturais, Universidade Estadual do Sudoeste da Bahia, \\ Estrada do Bem Querer km 4, CP 95, 45083-900 Vitória da Conquista-BA, Brazil
}

\begin{abstract}
Neste estudo, foi avaliada com base na variação temporal da condutividade elétrica (EC) e teores de sódio, potássio, cálcio e magnésio, a influência do regime de chuva no processo de salinização em dois reservatórios do sudoeste da Bahia, Brasil, cujas características se diferenciam por localizarem-se em dois diferentes climas (semi-árido e úmido). Para esse fim, dois reservatórios construídos sobre cursos de água da vertente oceânica foram escolhidos: o reservatório Anagé, localizado na zona semi-árida e o reservatório Água Fria, localizado na zona de transição da mata atlântica. As determinações de $\mathrm{Na}, \mathrm{K}, \mathrm{Ca}$ e Mg foram realizadas através de espectrometria de absorção atômica por chama (FAAS). Os resultados obtidos deste estudo indicam que a circulação e a distribuição das espécies químicas em ambos os sistemas aquáticos são relativamente bem definidas. Entretanto, foi observado que as águas do reservatório Anagé apresentaram as maiores variações nos valores da condutividade elétrica e da razão de adsorção do sódio (SAR) entre os dois períodos de coleta, demonstrando assim, uma maior influência do regime de chuva na qualidade da água dos reservatórios localizados na região semi-árida.
\end{abstract}

In this study, the influence of the rainfall variability in the salinization process in surface water reservoirs located in two distinct regions in southwestern Bahia, Brazil was evaluated with basis in the temporal variation of electric conductivity (EC), sodium, potassium, calcium and magnesium contents on the water samples collected in the reservoirs. Two reservoirs built on ocean watercourses were chosen: the Anagé reservoir, situated in the semi-arid zone and the Água Fria reservoir, located in the atlantic forest transition zone. The determination of $\mathrm{Na}, \mathrm{K}, \mathrm{Ca}$ and $\mathrm{Mg}$ were carried out by flame atomic absorption spectrometry (FAAS). The result obtained from this study indicates that the circulation and distribution of the chemical species in both water systems are relatively well defined. However, the water from the Anagé reservoir presented the largest variations in the values of the electric conductivity and sodium adsorption ratio (SAR) between of two collection periods, demonstrated a larger influence of the rain regime in the water quality of reservoir located in semi-arid zones.

Keywords: salt accumulation, sodium adsorption ratio, humid and semi-arid climates

\section{Introduction}

It is estimated that there are approximately 3.5 million hectares of irrigated land in Brazil. A little more than 500,000 hectares of this land are situated in the semiarid region. Large-scale irrigation in northeastern Brazil was introduced at the end of the 1960s by the Federal Government through the Multi-Annual Irrigation Program PPI. The main goal of this program was to implement irrigation and drainage studies, projects and operations pertaining to water supply in the semi-arid region. ${ }^{1-6}$

\footnotetext{
*e-mail: zesoares25@hotmail.com
}

The southwestern Bahia region, located in climatic transition zones, encompasses the atlantic forest, and it contains caatinga (semi-arid) vegetation. Damming has occurred in the semi-arid zone to stock water resources from the rainy season for use in the dry season. There are more than two-dozen medium- and large-sized dams in the region, with a total available storage capacity of more than two billion cubic meters of water. However, the quality of a significant part of this stored water has deteriorated due to salinization. ${ }^{7-10}$ However, even though only a portion of its water potential is used, this semi-arid area of southwestern Bahia has achieved a prominent position as one of the most important irrigated fruit producing zones in Brazil. 
In areas of climatic transition, water resources are more abundant, and rain is more intense and frequent. Therefore, there is less need to activate dams in transition zones than in semi-arid zones. Over the past few decades, beneficial weather conditions have transformed this area into an important coffee producing center.

Similar to the semi-arid zone, irrigated agriculture contributes significantly to ensuring the development of crops and, consequently, financial stability and food diversity, thus ensuring the sustainability of existing agroecosystems.

This study aimed to assess the influence of the rainfall regime in the salinization process in two reservoirs in southwestern Bahia, Brazil, whose characteristics are different because they are located in two different climates (semi-arid and humid). Two reservoirs built on ocean watercourses were chosen: the Anagé reservoir, situated in the semi-arid zone, has an average annual rainfall below $700 \mathrm{~mm}$; the Água Fria reservoir, located in the atlantic forest transition zone, has an average annual rainfall above $1,000 \mathrm{~mm}$, and its waters are used to supply the city of Vitória da Conquista. The flows of these watercourses are subject to considerable seasonal variability.

\section{Experimental}

\section{Problem definition}

The study area is located in the state of southwestern Bahia near the city of Vitória da Conquista (Figure S1, see Supplementary Information, SI). The region is constituted of two different climates, semi-arid and humid. The study was conducted at two reservoirs built on ocean watercourses that have highly variable flows depending on the season: the Anagé reservoir, located in the Contas River basin; and the Água Fria reservoir, situated in the Pardo River basin. These basins drain several different climates, including some agricultural areas, which significantly influences the physical-chemical characteristics of their waters.

The Anagé reservoir, which has a 255,630,000 $\mathrm{m}^{3}$ storage capacity, was built in 1987 over the Gavião River, a tributary of the Contas River basin that is situated in a low density demographic zone. The main drivers of development in this area are family agriculture and irrigated fruit crops. The climate is typical of semi-arid zones, with small amounts of rainfall that mostly occur during the summer.

In semi-arid regions, irrigated agriculture contributes significantly to the production of profitable crops, enhancing financial stability and providing dietary diversity for small farmers, thus ensuring the sustainability of existing agro-systems.
The Água Fria reservoir, with a storage capacity of $300,000 \mathrm{~m}^{3}$, was built in 1982 in the municipality of Barra do Choça in a region that is an important coffee producing center. The dam is situated in the Pardo River basin in an atlantic forest transition zone. This reservoir is notable for its wide network of tributaries, which gives it strategic importance in supplying water to the cities of Vitória da Conquista and Barra do Choça, as well as the regions of Barra Nova, José Gonçalves, São Sebastião, Bate Pé, Pradoso and Iguá, benefiting more than 350,000 inhabitants.

For much of the coffee crop in the region, the growth on the coffee plantations is mediated through crop irrigation during the dry seasons. This procedure can result in an increase of soluble salts in planted soils, thereby increasing the mobility of the soluble chemical species in the reservoir's drainage area. Therefore, studying the seasonal variations of $\mathrm{Na}^{+}, \mathrm{K}^{+}, \mathrm{Ca}^{2+}$ and $\mathrm{Mg}^{2+}$ concentrations in both reservoirs is extremely important for the determination and implementation of appropriate management strategies for irrigation procedures that aim to preserve water resources and soil quality.

The quality of the water used for irrigation influences not only the plants, but also the soil properties, possibly contributing to degradation processes that cause salinization or sodicity in the soil. Problems such as these may reduce the productivity of an area or even render it completely unproductive.

\section{Collection procedure}

Initially, a broad study was conducted in both reservoirs and their main tributaries. Later, a water sample collection schedule was established in points distributed throughout both reservoirs. In the Anagé reservoir, the sampling plan consisted of four points. Points A1 and A3 were situated, respectively, at the beginning and end of the main body of the reservoir (Figure S1), opposite from point A4. The latter was situated in an unexplored area with dense vegetation. This area was not under any influence of urban settlements, and is the main water body feeding the Gavião River, which is also its main outflow. The assessment of the upstream reservoir was conducted at point A2, situated at Riachão River.

Furthermore, characteristics of the soils and water from the small reservoirs located in the drainage basin of the Anagé reservoir collected in the dry period of 2007 were included in present work. The $\mathrm{Na}^{+}, \mathrm{Ca}^{2+}$ and $\mathrm{Mg}^{2+}$ concentrations of the water samples collected in September of 2007 in three small reservoirs (R1, R2 and R3) and surface soils samples ( 1, S2 and S3) simultaneously collected at sites located around of those small reservoirs 
Table 1. Mineral characteristics of the soils and water from the small reservoirs located in the drainage basin of the Anagé reservoir in the dry period of 2007

\begin{tabular}{|c|c|c|c|c|c|c|}
\hline & \multicolumn{3}{|c|}{ Small reservoirs } & \multicolumn{3}{|c|}{ Soils } \\
\hline & $\mathrm{R} 1$ & $\mathrm{R} 2$ & R3 & S1 & S2 & S3 \\
\hline $\mathrm{Na}^{+} /\left(\mathrm{mg} \mathrm{L}^{-1}\right)$ & $155.9 \pm 1.3$ & $139.2 \pm 1.0$ & $55.9 \pm 0.8$ & $769 \pm 2.0$ & $1679 \pm 3.0$ & $962 \pm 2.0$ \\
\hline $\mathrm{Ca}^{2+} /\left(\mathrm{mg} \mathrm{L}^{-1}\right)$ & $48.0 \pm 0.6$ & $56.0 \pm 1.0$ & $32.1 \pm 0.6$ & $2785 \pm 5.0$ & $13677 \pm 4.0$ & $2300 \pm 4.0$ \\
\hline $\mathrm{Mg}^{2+} /\left(\mathrm{mg} \mathrm{L}^{-1}\right)$ & $50.6 \pm 0.1$ & $28.6 \pm 0.4$ & $30.7 \pm 0.5$ & $1868 \pm 5.0$ & $5946 \pm 6.0$ & $3557 \pm 4.0$ \\
\hline
\end{tabular}

are summarized in the Table 1. Each soil sample (about $1 \mathrm{~kg}$ ) was a composite of five sub-samples taken from depths of 0 to $20 \mathrm{~cm}$. Exchangeable cations $\left(\mathrm{Na}^{+}, \mathrm{Ca}^{2+}\right.$ and $\mathrm{Mg}^{2+}$ ) were extracted from the soil with ammonium acetate (pH 7.0). ${ }^{11}$ The data presented in Table 1, will be used to verify the occurrence of the discharge of saline waters coming from small reservoirs into the Anagé reservoir during the rainy period.

At the Água Fria dam, three points were assessed in the main reservoir (P3, P4 and P5), and two points were situated downstream, one in the Água Fria River (P1) and the other in the Momos River (P2). Each of the collection stations was geo-referenced with a global positioning system (GPS), as indicated in Table 2 and Figure S1.

Table 2. Sampling points in the reservoirs Anagé and Água Fria and their characteristics (see Figure S1 for map details)

\begin{tabular}{|c|c|c|}
\hline Point & Characteristics & Coordinates (GPS) \\
\hline $\mathrm{P} 1$ & $\begin{array}{l}\text { Água Fria reservoir (a small pond, } \\
\text { situated downstream to the reservoir) }\end{array}$ & $\begin{array}{l}14^{\circ} 57^{\prime}, 48,4^{\prime \prime} \text { South } \\
40^{\circ} 34^{\prime} 12,1 \text { " West }\end{array}$ \\
\hline $\mathrm{P} 2$ & $\begin{array}{l}\text { Água Fria reservoir (Monos river, } \\
\text { situated downstream to the reservoir) }\end{array}$ & $\begin{array}{l}14^{\circ} 57^{\prime} 48,4^{\prime \prime} \text { South } \\
40^{\circ} 34^{\prime} 47^{\prime} \text { 'West }\end{array}$ \\
\hline P3 & $\begin{array}{l}\text { Água Fria reservoir (situated in the } \\
\text { beginning of the main body of the } \\
\text { reservoir) }\end{array}$ & $\begin{array}{l}14^{\circ} 55^{\prime} 26,5^{\prime} \text { " South } \\
40^{\circ} 35,33,5^{\prime} \text { West }\end{array}$ \\
\hline $\mathrm{P} 4$ & $\begin{array}{l}\text { Água Fria reservoir (situated in the end of } \\
\text { the main body of the reservoir) }\end{array}$ & $\begin{array}{l}14^{\circ} 55^{\prime} 36,7^{\prime \prime} \text { South } \\
40^{\circ} 04^{\prime} 22^{\prime} \text { West }\end{array}$ \\
\hline P5 & $\begin{array}{l}\text { Água Fria reservoir (located in the outlet } \\
\text { of the reservoir) }\end{array}$ & $\begin{array}{l}14^{\circ} 54^{\prime} 37,2^{\prime \prime} \text { South } \\
40^{\circ} 34^{\prime} 22,5^{\prime \prime} \text { West }\end{array}$ \\
\hline A1 & $\begin{array}{l}\text { Anajé reservoir (situated in the beginning } \\
\text { of the main body of the reservoir) }\end{array}$ & $\begin{array}{l}14^{\circ} 57^{\prime}, 48,4^{\prime \prime} \text { South } \\
40^{\circ} 34^{\prime} 12,1 \text { " West }\end{array}$ \\
\hline A2 & $\begin{array}{l}\text { Anajé reservoir (Riachão stream, } \\
\text { important tributary of the reservoir) }\end{array}$ & $\begin{array}{l}14^{\circ} 57^{\prime} 48,4 \text { "' South } \\
40^{\circ} 34^{\prime} 47^{\prime} \text { "West }\end{array}$ \\
\hline A3 & $\begin{array}{l}\text { Anaje reservoir (situated in the end of the } \\
\text { main body of the reservoir) }\end{array}$ & $\begin{array}{l}14^{\circ} 55^{\prime}, 26,5^{\prime \prime} \text { South } \\
40^{\circ} 35^{\prime} 33,5^{\prime} \text { West }\end{array}$ \\
\hline A4 & $\begin{array}{l}\text { Anajé reservoir (situated in an unexplored } \\
\text { area with dense vegetation) }\end{array}$ & $\begin{array}{l}14^{\circ} 55^{\prime} 26,7 \text { " South } \\
40^{\circ} 04^{\prime} 41^{\prime \prime} \text { West }\end{array}$ \\
\hline
\end{tabular}

Due to the variation in important regulating parameters of the dynamics of chemical species in such water bodies, the plan for water collection was based on the irregular rain distribution in the region. The collections were conducted at the beginning of (December 2007) and during the rainy season (February 2008).
Water samples were collected as described by Branco et al., ${ }^{5}$ in conformity with the official protocols, CETESB ${ }^{12}$ and standard methods for the examination of water and wastewater, APHA. ${ }^{13}$ To avoid the introduction of surface contaminants, the water samples were collected $2 \mathrm{~m}$ from the shore by submerging polystyrene bottles down to a depth of $50 \mathrm{~cm}$. The bottles were placed so that the opening would face away from the current. Finally, the bottles were slowly inclined upward to release the air and, subsequently, be filled with water. After each bottle was taken out of the water, a small portion of the sample was thrown away, leaving enough empty space to allow for the homogenization of the sample. The samples were preserved by adding nitric acid until they reached $\mathrm{pH} 2$. The samples used for determining the electrical conductivity (EC) and $\mathrm{pH}$ were placed in a cooler with ice immediately after collection, satisfying the requirements for dark and low temperatures.

\section{Analytical procedures}

The determination of $\mathrm{Na}, \mathrm{K}, \mathrm{Ca}$ and $\mathrm{Mg}$ were carried out by flame atomic absorption spectrometry (FAAS) using an Analyst 200 (USA) atomic absorption spectrometer equipped with a deuterium background corrector. The response from the instrument was periodically checked with known concentration patterns. The data acquisition system was managed by a computer connected to the atomic absorption spectrometer, and hollow cathode lamps composed of their respective elements were used as radiation sources. Based on the manufacturer's recommendations, the air-acetylene flame was used to quantify the four elements in the study. To obtain the K, $\mathrm{Ca}$ and $\mathrm{Mg}$ absorption signals, the following parameters were used: a slit width of $0.7 \mathrm{~nm}$ and wavelengths of 766, 423 and $285 \mathrm{~nm}$, respectively. For $\mathrm{Na}$, the wavelength was $589 \mathrm{~nm}$, and the slit width was $0.4 \mathrm{~nm}$.

Due to the lack of flame photometric equipment, the determinations of $\mathrm{Na}$ and $\mathrm{K}$ were conducted by FAAS. To control the ionization of these elements, $\mathrm{CsCl}(0.1 \%)$ was added to the patterns and to the samples. Also, to avoid the interference of some existing elements in the matrix during the determination of $\mathrm{Ca}$ and $\mathrm{Mg}, \mathrm{LaCl}_{2}(0.1 \%)$ was added to the patterns and to the samples. 
The physicochemical analyses were conducted with the use of a Digimed bench pH meter, model DM 20, and a CAAL bench conductivity meter, model MCA-150.

\section{Results and Discussion}

\section{Analytical performance}

The analytical performance characteristics for the extraction/analysis procedure to detect and quantify $\mathrm{Na}, \mathrm{K}, \mathrm{Ca}$ and $\mathrm{Mg}$ F AAS in soil and water samples are summarized in Table 3. The calibration curves obtained for all elements were linear with correlation coefficients of at least 0.9988 . The limit of detection (LOD) and limit of quantitation (LOQ) were calculated as three times and ten times, respectively, the standard deviation of the blank signal $(n=12)$ divided by the slope of each calibration graph. Precision was evaluated in terms of repeatability (inter-day) and reproducibility (intra-day), and it was determined using the relative standard deviations (RSDs) of the blank signal $(n=12)$ for each one of the elements $(\mathrm{Na}, \mathrm{K}, \mathrm{Ca}$ and $\mathrm{Mg}$ ). In order to test whether there was a significant difference in metal contents between results obtained in the water samples from each one of reservoir, paired two-tailored $t$-tests were performed.

\section{Effects of weather on the salinization process of the Anajé reservoir}

Preliminary studies conducted by Santos et al. ${ }^{4}$ to evaluate the climatic influence on the salinization process in the basin of the Anajé reservoir showed that after intense rainy periods (above $350 \mathrm{~mm}$ ), the $\mathrm{Na}^{+}, \mathrm{K}^{+}, \mathrm{Ca}^{2+}$ and $\mathrm{Mg}^{2+}$ concentrations in the tributary waters were significantly higher than those collected from the reservoir water during the same period. This result was attributed to the discharge of salinated water coming from the small reservoirs that are present throughout the draining area in times of high rainfall indexes. The excess of rain, combined with the intense surface runoff that is typical of the semi-arid region, promotes floods in the small reservoirs throughout the river basin, which culminates in the disruption of its levees. With such disruption, the salinated water of the small reservoirs is drained into the large reservoirs. Over the medium and long term, this salinization process causes problems with use of the reservoir water for irrigation.

Based on the results of the collections, shown in Table 4, the water at points $\mathrm{A} 1$ and $\mathrm{A} 3$, situated at the beginning and end of the main body of the reservoir, respectively, showed similar conductivity measures in the two collection periods (December 2007, 307 and $290 \mu \mathrm{S} \mathrm{cm}^{-1}$ and February 2008, 316 and $361 \mu \mathrm{S} \mathrm{cm}^{-1}$ ).

The upstream waters of the reservoir (point A2) showed very different characteristics compared with those of points A1 and A3. A significant increase was observed in the EC values between the two collection periods, with values of $403 \mu \mathrm{S} \mathrm{cm} \mathrm{cm}^{-1}$ in December 2007 and $1,611 \mu \mathrm{S} \mathrm{cm}^{-1}$ in February 2008.

In turn, the water at point A4, situated in the isolated branch of the reservoir, revealed EC values that were similar in both collections, but they were in discord with the hydro-chemical standards of the reservoir, with values of $1,054 \mu \mathrm{S} \mathrm{cm}^{-1}$ in December 2007 and $1,141 \mu \mathrm{S} \mathrm{cm}^{-1}$ in February 2008. These values are around four times higher than those obtained at the other two points in the reservoir (A1 and A3), indicating a drastic increase in the salinization process of the water in this branch of the reservoir, as the $\mathrm{EC}$ of $1,500 \mu \mathrm{S} \mathrm{cm} \mathrm{cm}^{-1}$ corresponds to a dissolved salt concentration of approximately $1 \mathrm{~g} \mathrm{~L}^{-1}$.

The high EC values measured at point A4 in the two collection periods, and at point $\mathrm{A} 2$ in the second collection, corroborate the hypothesis that flooding influences the semiarid reservoir salinization process, which was observed by Santos et al. ${ }^{4}$ as the two collections were conducted in periods when floods occurred in the region. In the December 2007 collection, at the beginning of the rainy season, $130.6 \mathrm{~mm}$ rainfall was recorded, of which, $73.3 \mathrm{~mm}$ occurred the week before the collections. In the February 2008 collection, when even higher rainfall indexes were recorded in the region, around $220 \mathrm{~mm}$ was recorded monthly. Therefore, the increase in salinity observed in the water collected at points $\mathrm{A} 2$ and $\mathrm{A} 4$ could be attributed to the drainage of salty water coming from the overflow of the small reservoirs in the watershed that feeds the reservoir and its tributaries.

It is important to stress that rain falling directly on the surface of reservoirs represents a simple dilution, but water

Table 3. Figure of merit of the analysis procedure

\begin{tabular}{lccccc}
\hline Elements & $\mathrm{LOD} /\left(\mathrm{mg} \mathrm{L}^{-1}\right)$ & $\mathrm{LOQ} /\left(\mathrm{mg} \mathrm{L}^{-1}\right)$ & Repeatability / (\%RSD) & Reproducibility / (\%RSD) & Correlation coefficient \\
\hline $\mathrm{Na}$ & 0.08 & 0.27 & 3.8 & 4.0 & 0.9996 \\
$\mathrm{~K}$ & 0.12 & 0.41 & 2.8 & 3.2 & 0.9999 \\
$\mathrm{Ca}$ & 0.14 & 0.45 & 3.0 & 3.5 & 0.9994 \\
$\mathrm{Mg}$ & 0.17 & 0.49 & 4.2 & 4.2 & 0.9988 \\
\hline
\end{tabular}


Table 4. Mean metal concentrations and $\mathrm{pH}$, electric conductivity (EC) and total dissolved solids (TDS) measures of the water samples collected from the Anagé reservoir

\begin{tabular}{|c|c|c|c|c|c|}
\hline & & $\mathrm{A} 1$ & $\mathrm{~A} 2$ & $\mathrm{~A} 3$ & A4 \\
\hline \multirow[t]{7}{*}{ Dec/2007 } & $\mathrm{pH}$ & 7.60 & 7.30 & 8.10 & 8.40 \\
\hline & $\mathrm{EC} /\left(\mu \mathrm{S} \mathrm{cm}^{-1}\right)$ & 307 & 403 & 290 & 1054 \\
\hline & $\mathrm{TDS} /\left(\mathrm{mg} \mathrm{L}^{-1}\right)$ & 159 & 202 & 158 & 531 \\
\hline & $\mathrm{Na}^{+} /\left(\mathrm{mg} \mathrm{L}^{-1}\right)$ & $85.5 \pm 0.6 \mathrm{a}$ & $94.5 \pm 0.05 b$ & $89.5 \pm 0.1 \mathrm{c}$ & $247 \pm 1.0 \mathrm{~d}$ \\
\hline & $\mathrm{K}^{+} /\left(\mathrm{mg} \mathrm{L}^{-1}\right)$ & $6.89 \pm 0.03 \mathrm{a}$ & $7.80 \pm 0.03 b$ & $6.70 \pm 0.02 \mathrm{a}$ & $7.00 \pm 0.04 \mathrm{ab}$ \\
\hline & $\mathrm{Ca}^{2+} /\left(\mathrm{mg} \mathrm{L}^{-1}\right)$ & $16.5 \pm 0.1 \mathrm{a}$ & $9.96 \pm 0.02 b$ & $16.6 \pm 0,05 a$ & $81.8 \pm 0.3 c$ \\
\hline & $\mathrm{Mg}^{2+} /\left(\mathrm{mg} \mathrm{L}^{-1}\right)$ & $20.0 \pm 0.3 \mathrm{a}$ & $23.4 \pm 0.1 b$ & $20.4 \pm 0.1 \mathrm{a}$ & $57.1 \pm 0.1 \mathrm{c}$ \\
\hline \multirow[t]{7}{*}{$\mathrm{Feb} / 2008$} & $\mathrm{pH}$ & 7.00 & 7.90 & 7.50 & 7.60 \\
\hline & $\mathrm{EC} /\left(\mu \mathrm{S} \mathrm{cm}^{-1}\right)$ & 316 & 1611 & 361 & 1141 \\
\hline & TDS / (mg L-1) & 141 & 697 & 166 & 481 \\
\hline & $\mathrm{Na}^{+} /\left(\mathrm{mg} \mathrm{L}^{-1}\right)$ & $65.2 \pm 0.2 \mathrm{a}$ & $250 \pm 1.0 \mathrm{~b}$ & $70.2 \pm 0.2 c$ & $228 \pm 1.0 \mathrm{~d}$ \\
\hline & $\mathrm{K}^{+} /\left(\mathrm{mg} \mathrm{L}^{-1}\right)$ & $5.90 \pm 0.20 \mathrm{a}$ & $20.0 \pm 0.3 b$ & $4.10 \pm 0.20 c$ & $4.50 \pm 0.30 c$ \\
\hline & $\mathrm{Ca}^{2+} /\left(\mathrm{mg} \mathrm{L}^{-1}\right)$ & $12.2 \pm 0.05 \mathrm{a}$ & $85.1 \pm 1.00 \mathrm{~b}$ & $13.9 \pm 0.10 c$ & $86.7 \pm 1.20 \mathrm{~b}$ \\
\hline & $\mathrm{Mg}^{2+} /\left(\mathrm{mg} \mathrm{L}^{-1}\right)$ & $15.4 \pm 0.4 \mathrm{a}$ & $107 \pm 1.0 \mathrm{~b}$ & $16.8 \pm 0.5 \mathrm{c}$ & $57.8 \pm 0.1 \mathrm{~d}$ \\
\hline
\end{tabular}

Mean values with the same letters for the same variable between the four collection points are not significantly different at the 5\% level (using a paired t-test analysis).

that drains as a result of rain falling on the watershed goes through the surface, leaching the land (soils and sediments) and constantly interacting with materials it encounters before it arrives at the reservoirs. These interactions depend mainly on the duration of contact and the characteristics of the solution and of the material, each of which change in space and time. The first runoffs from the rainy season are usually more concentrated because they bring the chemical species that were accumulated in the soil during the dry season resulting from the evaporation of water bodies. However, the soluble load from an affluent varies over the course of a rain event, from the beginning of the runoff to the recession of the floods. These episodes also vary for each rainfall during the rainy season. ${ }^{14-18}$

To support the previous considerations, ternary diagrams of percentage equivalents of $\mathrm{Na}^{+}, \mathrm{Ca}^{2+}$ and $\mathrm{Mg}^{2+}$ (Figure 1) were plotted to evaluate the evolution of solutes from the small reservoirs located in the drainage basin to Anagé reservoir in rainy period. These diagrams reveal the analogies, dissimilarities and different types of waters in the study area.

The Figure 1 shown that the ternary plots corroborate the conclusions previously obtained. The ternary plots (Figures 1a and 1b) also reveal the similarity of the relative concentrations of $\mathrm{Na}^{+}, \mathrm{Ca}^{2+}$ and $\mathrm{Mg}^{2+}$ in the water samples from the points $\mathrm{A} 1$ and $\mathrm{A} 3$ in the two collection periods (December 2007 and February 2008). As already mentioned, no similarity between the water samples from the point A2 collected in December of 2007 and any other water sample of Anagé reservoir is evident in Figure S1a. However, high similarity between the water of this point and water of two small reservoirs (R1 and R2) collected in dry period
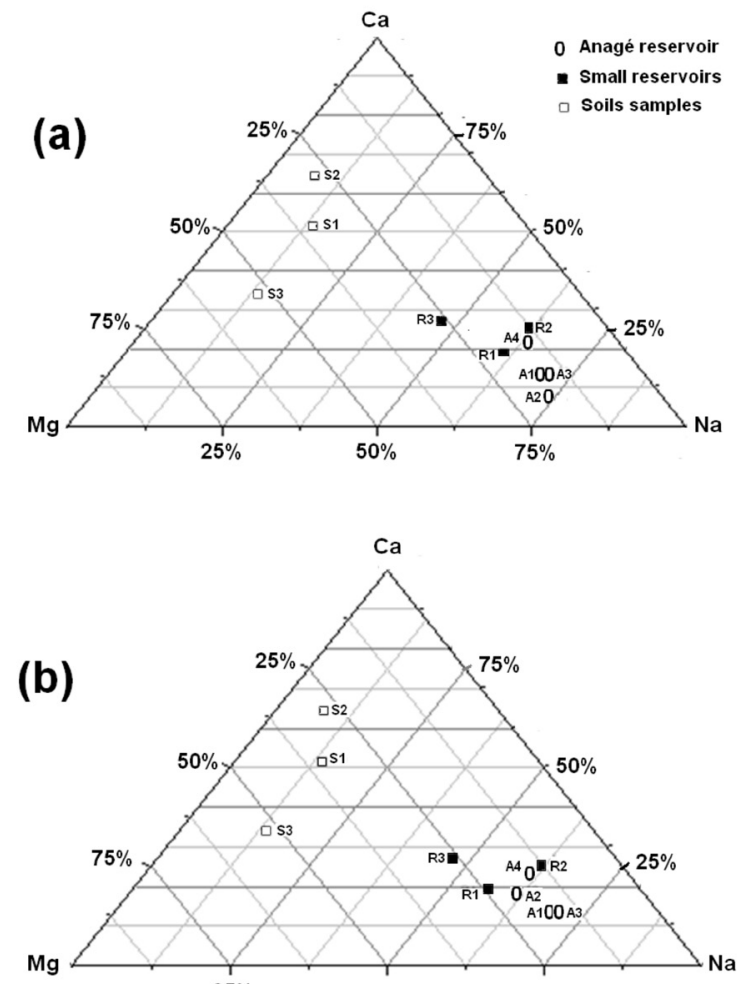

Figure 1. Ternary diagrams $\left(\mathrm{Na}^{+}, \mathrm{Ca}^{2+}\right.$ and $\left.\mathrm{Mg}^{2+}\right)$ for data of the Table 1 and water samples collected in the Anagé reservoir: (a) December 2007; (b) February 2008.

(september 2007), indicates that the chemical characteristics of the water of point A2 in December of 2007 was strongly influenced by the high concentration of the $\mathrm{Na}^{+}, \mathrm{Ca}^{2+}$ and $\mathrm{Mg}^{2+}$ detected in the water these small reservoirs (Table 1).

Other important information is revealed with the behavior of the samples of poins (A4) in the ternary 
diagrams (Figure 1b). As it can be seen, there is a similarity between the compositions of these waters with the waters collected in the points A2, R1 and R2. This fact leads the confirmation of the hypothesis that the increase of the salinity in the water of the points A2 (collected in December of 2007 and February of 2008) and A4 (collected in February of 2008) could be attributed to the drainage of salty water coming from the overflow of the small reservoirs in the watershed that feeds the reservoir and its tributaries.

The first runoffs from the rainy season are usually more rich in $\mathrm{Ca}^{2+}$ and $\mathrm{Mg}^{2+}$ because they bring the chemical species that were accumulated in the soil during the dry season, but before it empties into the lake where their concentrations decrease due to the chemical precipitation as suggested by Santos et al. ${ }^{9}$

\section{Evaluation of the salinization process in the Água Fria reservoir}

Table 4 shows the average values of the $\mathrm{Na}^{+}, \mathrm{K}^{+}$, $\mathrm{Ca}^{2+}$ and $\mathrm{Mg}^{2+}$ concentrations and the $\mathrm{pH}, \mathrm{EC}$ and total dissolved solids (TDS) measures of water samples collected from the Água Fria reservoir and its tributaries. In contrast to what was observed in the Anagé reservoir, the electrical conductivity values in the water collected from the Água Fria reservoir proved to be similar in both sampling periods. This phenomenon indicates that due to the humid climate, the salinization process of the Água Fria reservoir does not occur with the same intensity as the Anagé reservoir.

Based on the results in Tables 4 and 5, the evapoconcentration of the dissolved $\mathrm{Na}^{+}, \mathrm{K}^{+}, \mathrm{Ca}^{2+}, \mathrm{Mg}^{2+}$ species is evident in the semi-arid region water, and consequently, the concentrations of these species in the water at the four collection points situated in the Anagé reservoir are clearly higher than those collected from the five points in the Água Fria reservoir during the same period.

\section{Influence of meteorology on the quality of irrigation water}

The soil salinization and sodicity risks need to be evaluated when considering the possible use of these waters for irrigation. The Riverside laboratory defined two parameters for evaluating water quality: electrical conductivity (EC), which is related to the total soluble salt concentration, and thus indicates the risk of salinization; and the sodium adsorption ratio (SAR), which indicates the soil sodicity risk.

Based on the electrical conductivity values, five water classes were established for risk evaluation: $\mathrm{C} 1$ for low salinity $\left(\mathrm{EC}<250 \mu \mathrm{S} \mathrm{cm}^{-1}\right)$; $\mathrm{C} 2$ for medium salinity (EC between 250 and $750 \mu \mathrm{S} \mathrm{cm}^{-1}$ ); $\mathrm{C} 3$ for high salinity (EC between 750 and 2,250 $\mu \mathrm{S} \mathrm{cm}^{-1}$ ); C4 for very high salinity (EC between 2,250 and 5,000 $\mu \mathrm{S} \mathrm{cm}^{-1}$ ); and $\mathrm{C}$, which indicates that the water is not appropriate for use in irrigation $\left(\mathrm{EC}>5,000 \mu \mathrm{S} \mathrm{cm}^{-1}\right)$.

The sodium adsorption ratio, or SAR, expresses in a simple manner the relative proportion of sodium in relation to the addition of calcium and magnesium, which can be expressed by:

$$
\mathrm{SAR}=\frac{\mathrm{Na}^{+}}{\sqrt{\frac{\mathrm{Ca}^{+2}+\mathrm{Mg}^{+2}}{2}}}
$$

Table 5. Mean metal concentrations and pH, electric conductivity (EC) and total dissolved solids (TDS) measures of the water samples collected from the Água Fria reservoir

\begin{tabular}{|c|c|c|c|c|c|c|}
\hline & & $\mathrm{P} 1$ & $\mathrm{P} 2$ & $\mathrm{P} 3$ & $\mathrm{P} 4$ & P5 \\
\hline \multirow[t]{7}{*}{ Dec/2007 } & $\mathrm{pH}$ & 5.90 & 5.90 & 6.30 & 5.50 & 6.60 \\
\hline & $\mathrm{EC} /\left(\mu \mathrm{S} \mathrm{cm} \mathrm{cm}^{-1}\right)$ & 38.9 & 40.9 & 44.7 & 35.8 & 38.8 \\
\hline & TDS / $\left(\mathrm{mg} \mathrm{L}^{-1}\right)$ & 19.7 & 20.5 & 22.3 & 17.9 & 20.2 \\
\hline & $\mathrm{Na}^{+} /\left(\mathrm{mg} \mathrm{L}^{-1}\right)$ & $7.11 \pm 0.03 \mathrm{a}$ & $6.43 \pm 0.01 b$ & $8.10 \pm 0.03 c$ & $6.90 \pm 0.01 \mathrm{~d}$ & $6.78 \pm 0.02 \mathrm{e}$ \\
\hline & $\mathrm{K}^{+} /\left(\mathrm{mg} \mathrm{L}^{-1}\right)$ & $1.36 \pm 0.02 \mathrm{a}$ & $1.53 \pm 0.01 b$ & $1.68 \pm 0.01 \mathrm{c}$ & $1.31 \pm 0.01 \mathrm{a}$ & $1.40 \pm 0.02 \mathrm{~d}$ \\
\hline & $\mathrm{Ca}^{2+} /\left(\mathrm{mg} \mathrm{L}^{-1}\right)$ & $0.40 \pm 0.04 \mathrm{a}$ & $0.84 \pm 0.01 b$ & $0.50 \pm 0.04 \mathrm{c}$ & $0.46 \pm 0.01 \mathrm{ac}$ & $0.50 \pm 0.03 c$ \\
\hline & $\mathrm{Mg}^{2+} /\left(\mathrm{mg} \mathrm{L}^{-1}\right)$ & $0.46 \pm 0.01 \mathrm{a}$ & $0.72 \pm 0.02 b$ & $0.60 \pm 0.01 \mathrm{c}$ & $0.46 \pm 0.01 \mathrm{a}$ & $0.49 \pm 0.02 \mathrm{a}$ \\
\hline \multirow[t]{7}{*}{ Feb/2008 } & $\mathrm{pH}$ & 5.00 & 5.00 & 5.50 & 5.50 & 6.10 \\
\hline & $\mathrm{EC} /\left(\mu \mathrm{S} \mathrm{cm}^{-1}\right)$ & 39.8 & 41.2 & 42.7 & 33.8 & 36.6 \\
\hline & TDS / (mg L $\left.{ }^{-1}\right)$ & 20.7 & 21.3 & 23.2 & 19.7 & 22.0 \\
\hline & $\mathrm{Na}^{+} /\left(\mathrm{mg} \mathrm{L}^{-1}\right)$ & $6.27 \pm 0.02 \mathrm{a}$ & $5.85 \pm 0.01 b$ & $7.61 \pm 0.02 \mathrm{c}$ & $6.89 \pm 0.02 \mathrm{~d}$ & $6.68 \pm 0.02 \mathrm{e}$ \\
\hline & $\mathrm{K}^{+} /\left(\mathrm{mg} \mathrm{L}^{-1}\right)$ & $0.89 \pm 0.02 \mathrm{a}$ & $0.59 \pm 0.01 b$ & $2.29 \pm 0.02 c$ & $1.85 \pm 0.02 \mathrm{~d}$ & $1.67 \pm 0.01 \mathrm{~d}$ \\
\hline & $\mathrm{Ca}^{2+} /\left(\mathrm{mg} \mathrm{L}^{-1}\right)$ & $0.25 \pm 0.01 \mathrm{a}$ & $0.64 \pm 0.01 b$ & $0.36 \pm 0.01 \mathrm{c}$ & $0.34 \pm 0.01 \mathrm{c}$ & $0.32 \pm 0.02 c$ \\
\hline & $\mathrm{Mg}^{2+} /\left(\mathrm{mg} \mathrm{L}^{-1}\right)$ & $0.37 \pm 0.02 \mathrm{a}$ & $0.70 \pm 0.03 b$ & $0.64 \pm 0.05 b$ & $0.52 \pm 0.01 \mathrm{c}$ & $0.50 \pm 0.04 \mathrm{c}$ \\
\hline
\end{tabular}

Mean values with the same letters for the same variable between the five collection points are not significantly different at the $5 \%$ level (using a paired $t$-test analysis). 
This relative proportion is responsible for the substitution process of calcium and magnesium cations by sodium in the soil adsorption complex, a process called sodicity. The water classes proposed according to the SAR are the following: S1 for low sodicity risk (SAR $<10)$; S2 for medium sodicity risk $(10<\mathrm{SAR}<18)$; S3 for high sodicity risk $(18<\mathrm{SAR}<26)$; and $\mathrm{S} 4$ for very high sodicity risk $(\mathrm{SAR}>26) .{ }^{19-25}$

When the soil is irrigated with water having high sodium content, in addition to altering its permeability, it causes an imbalance in the ion exchange system of $\mathrm{Na}^{+}$in relation to $\mathrm{Ca}^{2+}$ and $\mathrm{Mg}^{2+}$, which negatively affects the availability of nutrients. ${ }^{10}$

By associating the results of electrical conductivity (Table 3) with the SAR values (Figure 1), it can be concluded that the water collected in December 2007 at points A1, A2 and A3 of the Anagé reservoir are to be classified as C2-S3. This collected water, when used for irrigation, represents a medium salinization risk with a high risk of soil sodicity. The water collected in February 2009 at the beginning and end of the main body of the reservoir (points A1 and A3) exhibited lesser SAR values. As a consequence, the classification of this water changed from C2-S3 in December 2007 to C2-S2 in February 2008, now showing a medium risk of sodicity. A great increase in water salinity occurred at point A2 in February 2008, which was indicated by the high EC values measured. However, the SAR values measured in that water revealed that no changes occurred in the relative sodium proportion connected to the addition of calcium and magnesium. For this reason, the classification of the water at this collection point changed from C2-S3 in December 2007 to C3-S3 in February 2008, thus presenting a higher salinization risk for irrigation use.

In turn, the $\mathrm{CE}$ and $\mathrm{SAR}$ values of the water from point A4 in both collections appeared to agree, though they were very high. Thus, the waters collected in December 2007 and February 2008 at point A4 were classified as C3-S4, showing very high salinity and sodicity values, and were thus considered inappropriate for irrigation.

Due to the semi-arid climate which is very suitable for the growth of mango, grape, papaya and coconut, the main agricultural activity in the studied region include irrigated orchards. However, the irrigation process is interrupted during the rainy season. Thus, water of high salinity values that were recorded in the samples of the point A4 of the two collection periods, and from point $\mathrm{A} 2$ of the second collection, are not used for the irrigation of orchards.

In contrast, Figure 2 shows that the SAR measured in the water collected in both periods at the Água Fria reservoir are all bellow the values obtained for the Anagé reservoir water. In contrast to the Anagé, all of the samples coming from the Água Fria reservoir fit into the $\mathrm{C} 1$ class, that is, low salinity water that does not present a risk for soil salinization when used in irrigation. However, for the sodicity risk in the December 2007 collection, only the water at points P2 and P5 were classified as S1 because they showed SAR values below 10 . The water collected from the other three collection points, P1, P3 and $\mathrm{P} 4$, showed a medium sodicity risk, and they were thus classified as $\mathrm{S} 2$.
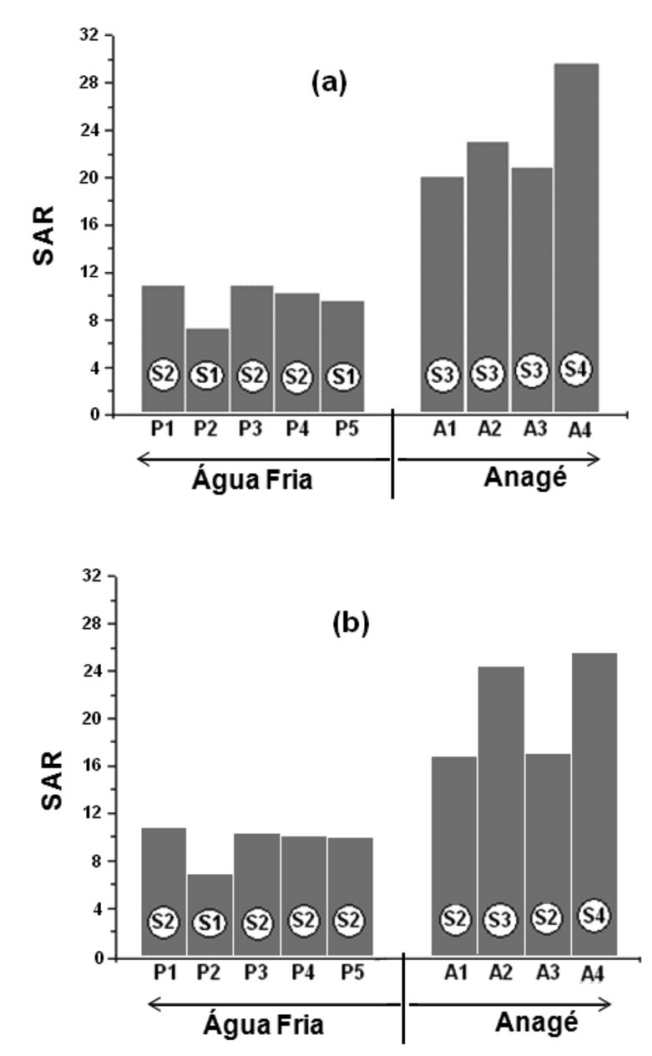

Figure 2. SAR variation in waters from the Água Fria and Anagé reservoirs for the two sampling periods: (a) December 2007; (b) February 2008.

In February 2008, probably due to the increased rainfall, an increase in the SAR value occurred for water collected at point P5, and its classification was altered to $\mathrm{S} 2$. Therefore, only the water at point $\mathrm{P} 2$ in this collection period showed low sodicity risk (S1). The water from the other points during this period showed a medium sodicity risk.

\section{Conclusions}

This study indicates that the circulation and distribution of the chemical species in both water systems are relatively well defined; however, their dynamics are influenced by climatic variations. 
At the beginning of the rainy season (December 2007), the water from most of the collection points from the Água Fria reservoir did not show any restrictions concerning use in irrigation, mostly matching classes $\mathrm{C} 1-\mathrm{S} 1$. In this collection period, only the waters at points $\mathrm{P} 3$ and $\mathrm{P} 4$ could be used for irrigation with caution, as they were classified as $\mathrm{C} 1-\mathrm{S} 2$, which shows a medium sodicity risk for soils. The influence of the rainfall regime on the water quality of this reservoir was evident from the February 2008 collection, when intense rain occurred. In this collection, only the water from $\mathrm{P} 2$ showed no restrictions to irrigation use because it remained classified as C1-S1, while the water from the rest of the collection points was classified as $\mathrm{C} 1-\mathrm{S} 2$.

In contrast, the water collected at the beginning of the rainy season (December 2007) at the Anagé Reservoir, situated in the semi-arid zone, was classified as C2-S3 for points A1, A2 and A3 and C3-S4 for point A4, which showed a high dissolved salt content and should be avoided for use in irrigation. However, in contrast to what occurred at the Água Fria reservoir, the water collected in February 2008 at points A1 and A3 from the Anagé reservoir showed SAR values below those observed in the previous collection, with a classification of C2-S2. That water can now be used for irrigation in most of the soils.

\section{Supplementary Information}

The map of the reservoirs and their respective collecting points are provided as supplementary information and available free of charge at http:// jbcs.sbq.org.br as PDF file.

\section{Acknowledgments}

The authors thank Fundação de Amparo a Pesquisa do Estado da Bahia (FAPESB) and Coordenação de Aperfeiçoamento de Pessoal de Nível Superior (CAPES) for financial support.

\section{References}

1. Valdes, A.; Wagner, E.; Marzall, I.; Simas, J.; Morelli, J.; Pereira, L. P.; Azevedo, L. G. T.; Impactos e Externalidades Sociais da Irrigação no Semi-Árido Brasileiro, $1^{\text {st }}$ ed., Banco Mundial: Brasília, 2004.

2. Santos, J. S.; Oliveira, E.; Massaro, S.; Quim. Nova 2000, 23, 453.

3. Prathumratana, L.; Sthiannopkao, S.; Kim, K. W.; Environ. Int. 2008, 34, 860 .
4. Santos, J. S.; Oliveira, E.; Bruns, R. E.; Gennari, R. F.; Water Res. 2004, 38, 1579.

5. Branco, S. M.; Porto, R. L. L.; Cleary, R. W.; Coimbra, R. M.; Eiger, S.; Luca, S. J.; Nogueira, V. P. Q.; Porto, M. F. A.; Hidrologia Ambiental, Edusp: São Paulo, Brasil, 1991.

6. Suassuna, J.; Ciência Hoje 1994, 18, 38.

7. Santos, J. S.; Santos M. J. S.; Santos, M. L. P.; Quim. Nova 2009, 32, 1534.

8. Maksoud, H.; Hidrologia e Possibilidades Hidroenergéticas da Bacia do Rio de Contas, na Bahia, IBGE: Rio de Janeiro, Brasil, 1964.

9. Santos, J. S.; Santos, M. L. P.; Oliveira, E.; Quim. Nova 2008, $31,1107$.

10. Lebron, I.; Suarez, D. L.; Amrhein, C.; Strong, J. E.; Clays Clay Miner. 1993, 41, 380.

11. Page, A. L.; Methods of Soil Analysis Part 2, American Society of Agronomy: Madison, Wisconsin, 1982.

12. Companhia de Tecnologia e Saneamento Ambiental; Guia de Coleta e Preservação de Amostras de Água, CETESB: São Paulo, Brasil, 1987.

13. APHA, AWWA, WEF; Standard Methods for the Examination of Water and Wastewater, $20^{\text {th }}$ ed., American Public Heath Association: Washington, 1998.

14. Göbel, P.; Dierkes, C.; Coldewey, W. G.; J. Contam. Hydrol. 2007, 91, 26.

15. Chalmers, A. T.; Van Metre, P. C.; Callender, E.; J. Contam. Hydrol. 2007, 91, 4.

16. Ellis, P. A.; Mackay, R.; Rivett, M. O.; J. Contam. Hydrol. 2007, 91, 58.

17. Mahler, B.; Massei, N.; J. Contam. Hydrol. 2007, 91, 81.

18. Felipe-Sotelo, M.; Andrade, J. M.; Carlosena, A.; Tauler, R.; Anal. Chim. Acta 2007, 583, 128.

19. Letey, J.; Feng, G. L.; Agric. Water Manage. 2007, 91, 1.

20. Sundaray, S. K.; Nayak, B. B.; Bhatta, D.; Environ. Monit. Assess. 2009, 155, 227.

21. Banoeng-Yakubo, B.; Yidana, S. M.; Nti, E.; Environ. Geol. 2009, 57, 1005.

22. Singh, R. B.; Chauhan, C. P. S.; Minhas, P. S.; Agric. Water Manage. 2009, 96, 736.

23. Leal, R. M. P.; Herpin, U.; Fonseca, A. F.; Firme, L. P.; Montes, C. R.; Melfi, A. J.; Agric. Water Manage. 2009, 96, 307.

24. Yidana, S.; Ophori, D.; Banoeng-Yakubo, B.; Environ Geol. 2008, 55, 1647.

25. Mandal, U. K.; Warrington, D. N.; Bhardwaj, A. K.; Bar-Tal, A.; Kautsky, L.; Minz, D.; Levy,G. J.; Geoderma 2008, 144, 189.

Submitted: October 12, 2010

Published online: March 31, 2011 


\section{Comparative Study of the Salinization Process in Surface Water Reservoirs Located in Two Distinct Regions in Southwestern Bahia, Brazil}

José S. dos Santos, * Maria Lúcia P. dos Santos and Daniela Marques Alexandrino

Departamento de Ciências Naturais, Universidade Estadual do Sudoeste da Bahia,

Estrada do Bem Querer km 4, CP 95, 45083-900 Vitória da Conquista-BA, Brazil

(a)
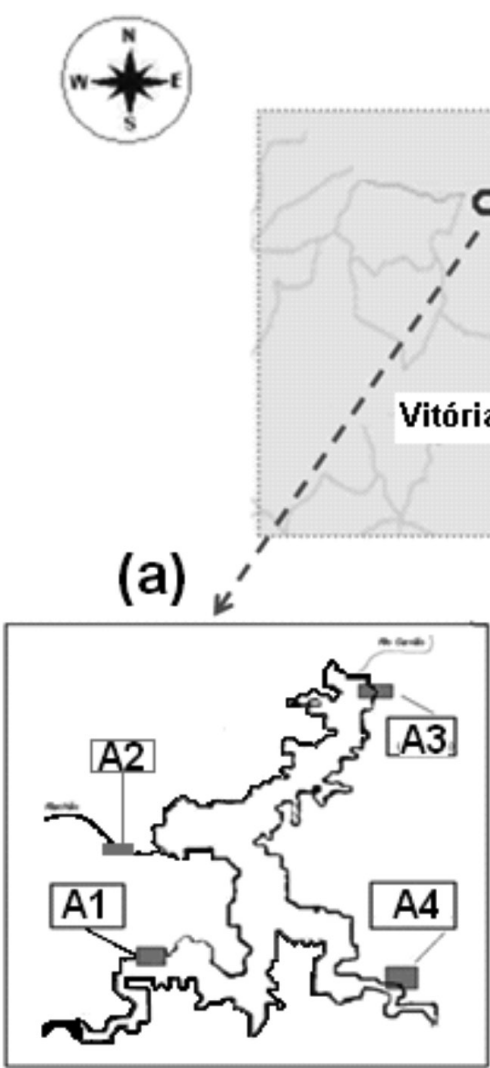
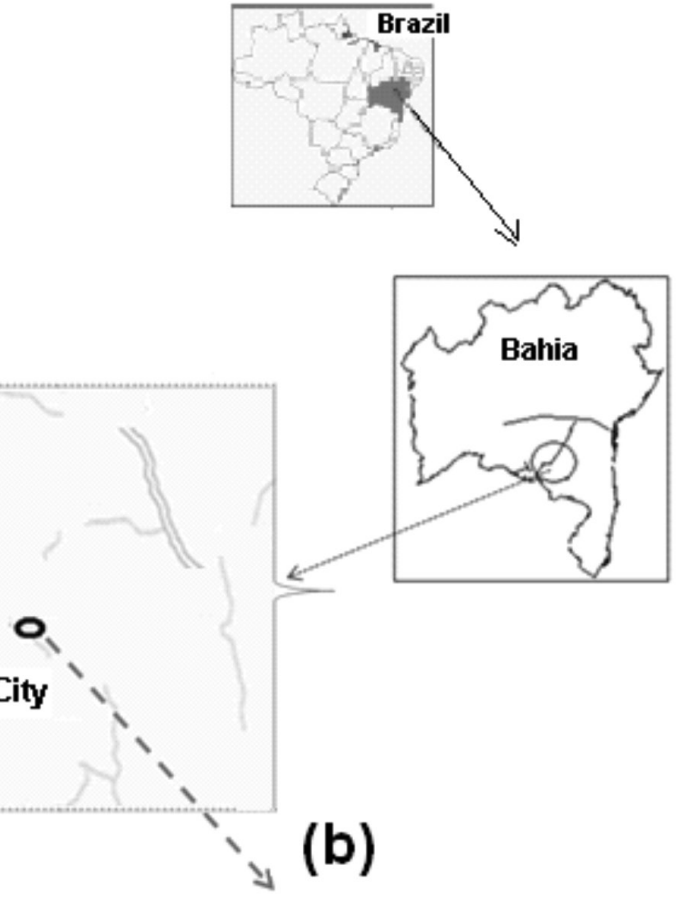

(b)

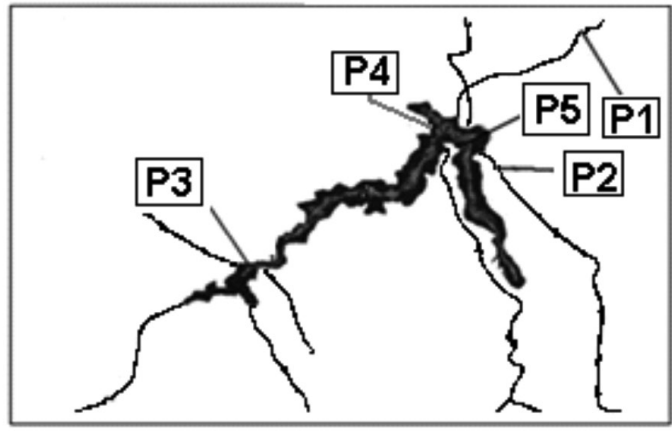

Figure S1. Reservoirs and their respective collecting points: (a) Anagé; (b) Água Fria. 